\title{
Bumping into the Glass Ceiling: Exploring Women's Experiences Seeking Positional Leadership Roles Within the Student Affairs Profession in South Africa
}

\author{
Jamie Storey ${ }^{\mathrm{a},{ }^{*}}$ \\ ${ }^{a}$ Central Michigan University, United States \\ *Corresponding author: Email: guiga1j1@cmich.edu. \\ Address: Central Michigan University, Michigan, United States
}

\section{Introduction}

Women in South Africa are not attaining positional leadership roles within student affairs at an equitable rate as their male counterparts (Person, Saunders, and Oganesian 2014; White, Bagilhole, and Riordan 2012). Student affairs in South Africa is a relatively new, burgeoning field in need of diverse, qualified professionals and effective leadership (Schreiber, Moja, and Luescher 2016; Selznick 2013). Women educators in South Africa face difficult challenges in a male-dominated environment. Despite various efforts to advance women within South African educational administration, gender biases and structural barriers exist, preventing women from progressing into leadership roles at an equitable rate (Person, Saunders, and Oganesian 2014). While women's experiences seeking leadership roles have been explored, few research studies focus on women seeking student affairs leadership roles in South Africa.

\section{Problem Statement}

The purpose of this phenomenological study is to explore the meaning women ascribe to the experience of seeking formal leadership positions within the field of student affairs in South Africa. Formal leadership positions are defined as directors, executive directors, deans, deputy vice chancellors, or vice chancellors. The overarching question guiding this study is: What is the lived experience of student affairs women professionals in South Africa who seek formal leadership positions? Further, I am considering two sub-questions throughout the study:

1. What meaning do student affairs women professionals make of the experience of seeking formal leadership positions in South Africa?

2. How do these women navigate work and family balance conflict while seeking formal leadership positions in student affairs in South Africa?

\section{Literature Review}

Research shows a considerable disparity between the number of women in the student affairs profession overall and the percentage who secure positional leadership roles (Bichsel and McChesney 2017; White, Bagilhole, and Riordan 2012). The incongruence among women professionals securing leadership positions at South African universities is no different (Mayer, Oosthuizen, and Surtee, 2017; Person, Saunders, and Oganesian 2014). As African institutions of higher education become more accessible, the need for skilled professionals increases. In turn, the demand for student affairs leaders reflective of the increasingly diverse student population intensifies and necessitates a review of equity among senior management positions (Schreiber, Moja, and Luescher 2016; Selznick 2013). 
While women are gaining ground in attaining leadership roles within higher education, there is little debate that barriers continue to prevent career advancement (Airini et al. 2011). Research indicates many factors impact women's movement into leadership roles (Diehl 2014). Stereotypes assuming women are less effective leaders than men continue to exist (Person, Saunders, and Oganesian 2014). Women are more likely than men to experience scrutinized credentials and skepticism concerning leadership (Hannum et al. 2015). Men often exclude women from networking, support systems, mentorship, and career advancement opportunities due to homosociability (Airini et al. 2011; Baltodano et al. 2012; White, Bagilhole, and Riordan 2012). As men continue to have stronger representation within higher education networks, they continue to influence hiring procedures and recruitment practices making it difficult for women to advance into leadership positions (Shepherd 2017).

Further, some research suggests that barriers at the societal and institutional level influence women's personal decision-making surrounding leadership aspirations (Airini et al. 2011; Diehl 2014). In South African society, women have been viewed as responsible for domestic roles and unable to devote time and energy to leadership positions within educational administration (Person, Saunders, and Oganesian 2014). According to some research, women consider the anticipation of conflicts between work and family and the lack of societal, institutional, and familial support when making decisions about leadership aspirations (Coyle et al. 2015; Ganginis Del Pino et al. 2013; Savela, and O'Brien 2016). By exploring women's experiences seeking positional leadership within the student affairs profession in South Africa, it is possible to achieve a stronger understanding of the barriers impeding desired career trajectory.

Using a phenomenological study explored through a feminist perspective centers women's attitudes surrounding the essence of seeking positional leadership roles. At its core, "feminist research is centrally defined by questions originating from a women's perspective" (Broido and Manning, 2002, p. 442). The feminist perspective emphasizes how individuals' experiences are influenced by gender within social and cultural contexts (Jones, Torres, and Arminio 2014). Further, feminist theory situates women's experiences into a broader, shared context which is consistent with the phenomenological research goal of defining a shared essence (Butler 1988).

\section{Methods}

Participants in the study identify as women student affairs professionals, 18+ years of age, who have sought or are seeking leadership positions in South Africa. According to Love (2003), student affairs consists of administrative functions outside the classroom within higher education. Invitations to participate in interviews were sent to women at all levels of the organization at five universities in South Africa, and I will select five who volunteer and identify with the criteria.

I am conducting in-depth, semi-structured interviews using open-ended questions that encourage participants to describe the meaning they make about experiences. All interviews will be audio recorded and transcribed. I will practice epoché, by reflecting on assumptions, judgments, and understandings of myself and the phenomenon (Creswell and Poth 2018). The data will be analyzed and contextualized within literature surrounding gendered leadership within student affairs in South Africa as well the United States. I will analyze the interviews by reviewing significant statements, constructing overarching themes, and creating a composition descriptive of the phenomenon.

\section{Conclusion}

The phenomenological study gives voice to women's personal narratives and experiences seeking progression into leadership positions in South Africa. Further, women's experiences seeking leadership within student affairs in South Africa will be contextualized and compared to women's experiences within the United States using the current literature base. In this way, the study fills a gap in research and literature. The study will inform higher education 
policy and women's leadership development programs. Finally, leaders understanding gender inequities can create environments that support women's desired career aspirations and aim to increase gender parity.

\section{References}

Airini, Sunny Collings, Lindsey Conner, Kathryn Mcpherson, Brenda Midson, \& Cheryl Wilson. 2011. "Learning to Be Leaders in Higher Education: What Helps or Hinders Women's Advancement as Leaders in Universities." Educational Management Administration \& $\quad$ Leadership $39 \quad$ (1): 44-62. https://doi.org/10.1177/1741143210383896.

Baltodano, Josefina Castillo, Susan Carlson, Leah Witcher Jackson, \& Wanda Mitchell. 2012. "Networking to Leadership in Higher Education." Advances in Developing Human Resources 14 (1): 62-78. https://doi.org/10.1177/1523422311428926.

Bichsel, Jacqueline, \& Jasper McChesney. 2017. "The Gender Pay Gap and the Representation of Women in Higher Education.” CUPA, https://www.cupahr.org/surveys/publications/research-briefs/.

Broido, Ellen, \& Kathleen Manning. 2002. "Philosophical Foundations and Current Theoretical Perspectives in Qualitative Research.” Journal of College Student Development 43 (4): 434-45.

Butler, Judith. 1988. "Performative Acts and Gender Constitution: An Essay in Phenomenology and Feminist Theory." Theatre Journal 40 (4): 519-31. https://doi.org/10.2307/3207893.

Coyle, Emily F., Elizabeth Van Leer, Kingsley M. Schroeder, \& Megan Fulcher. 2015. "Planning to Have It All: Emerging Adults' Expectations of Future Work-Family Conflict." Sex Roles 72: 547-57. https://doi.org/10.1007/s11199-015-0492-y.

Creswell, John W., \& Cheryl N. Poth. 2018. Qualitative Inquiry \& Research Design: Choosing among Five Approaches. Los Angeles: SAGE Publications.

Diehl, Amy. 2014. "Making Meaning of Barriers and Adversity: Experiences of Women Leaders in Higher Education." Advancing Women in Leadership 34: 54-63.

Ganginis Del Pino, Heather V., Karen M. Obrien, Ethan Mereish, \& Matthew J. Miller. 2013. “'Leaving before She Leaves': Considering Future Family When Making Career Plans.” Journal of Counseling Psychology 60 (3): 462 70. https://doi.org/10.1037/a0032651.

Hannum, Kelly, Shannon Muhly, Pamela Shockley-Zalabak, \& Judith White. 2015. "Women Leaders within Higher Education in the United States: Supports, Barriers, and Experiences of Being a Senior Leader." Advancing Women in Leadership 35: 65-75.

Jones, Susan R., Vasti Torres, and Jan L. Arminio. 2014. Negotiating the Complexities of Qualitative Research in Higher Education: Fundamental Elements and Issues. New York, NY: Routledge.

Love, Patrick. 2003. "Considering a Career in Student Affairs.” ACPA. http://www.myacpa.org/considering-careerstudent-affairs.

Mayer, Claude-Helene, Rudolf M. Oosthuizen, \& Sabie Surtee. 2017. "Emotional Intelligence in South African Women Leaders in Higher Education." SA Journal of Industrial Psychology 43: 1-12. https://doi.org/10.4102/sajip.v43i0.1405.

Person, Dawn, Katherine Saunders, \& Kristina Oganesian. 2014. "Building South African Women's Leadership: A Cohort Model for the $\mathrm{PhD}$ in Student Affairs." Journal of Student Affairs in Africa 2 (1): 9-22. https://doi.org/10.14426/jsaa.v2i1.47.

Savela, Alexandra E., \& Karen M. O’Brien. 2016. "Predicting College Women's Career Plans." Journal of Career Development 43 (4): 335-48. https://doi.org.10.1177/0894845315602118. 
Selznick, Benjamin. 2013. "A Proposed Model for the Continued Professionalisation of Student Affairs in Africa." Journal of Student Affairs in Africa 1 (1): 11-22. https://doi.org/10.14426/jsaa.v1i1-2.35.

Schreiber, Birgit, Teboho Moja, \& Theirry M. Luescher. 2016. "Student Affairs in Complex Contexts." Journal of Student Affairs in Africa 4 (2): v-viii. https://doi.org/10.14426/jsaa.v4i2.1526.

Shepherd, Sue. 2017. "Why Are There so Few Female Leaders in Higher Education." Management in Education 31 (2): 82-7. https://doi.org/10.1177/0892020617696631.

White, Kate, Barbara Bagilhole, \& Sarah Riordan. 2012. "The Gendered Shaping of University Leadership in Australia, South Africa and the United Kingdom.” Higher Education Quarterly 66 (3): 293-307. https://doi.org/10.1111/j.1468-2273.2012.00523.x 